\title{
KUALITAS AIR SUNGAI GAJAH WONG DITINJAU DARI PENGHAMBATAN ENZIM ASETILKOLINESTERASE \\ (Water Quality Assessment of Gajah Wong River Based on Inhibition of Acetylcholinesterase Activity)
}

\section{Florentinus Dika Octa Riswanto $^{1^{*},}$, Maywan Hariono ${ }^{1}$, Gatot Nugroho Susanto ${ }^{2,3}$, Ignatius Yulius Kristio Budiasmoro ${ }^{2,3}$, dan Enade Perdana Istyastono ${ }^{1,3}$}

\author{
${ }^{1}$ Program Studi Farmasi, Fakultas Farmasi Universitas Sanata Dharma, \\ Kampus III Paingan Maguwoharjo, Depok, Yogyakarta, 55282. \\ ${ }^{2}$ Program Studi Pendidikan Biologi, Fakultas Keguruan dan Ilmu Pendidikan, \\ Universitas Sanata Dharma, Kampus III Paingan Maguwoharjo, Depok, Yogyakarta, 55282. \\ ${ }^{3}$ Pusat Studi Lingkungan, Universitas Sanata Dharma, Soropadan, Condongcatur, \\ Depok, Yogyakarta 55283.
}

*Penulis korespondensi. Tel: 0274-883027 ext. 2328. Email: dikaocta@usd.ac.id.

Diterima: 10 Februari 2016

Disetujui: 6 Mei 2017

\begin{abstract}
Abstrak
Sungai Gajah Wong, salah satu sungai di kota Yogyakarta, dikhawatirkan terpapar pencemaran air akibat pembuangan limbah rumah tangga, industri, rumah sakit maupun hotel yang masuk ke dalam alirannya. Hal ini menyebabkan penurunan kualitas air sungai dan menimbulkan dampak negatif bagi makhluk hidup yang memanfaatkannya. Pencemaran air sungai tersebut dapat diamati secara biokimiawi berdasarkan uji aktivitas penghambatan enzim asetilkolinesterase (AChE) oleh cemaran pestisida organofosfat dan karbamat. Uji biokimiawi dalam analisis kualitas air terhadap penghambatan AChE dapat dilakukan secara kolorimetrik menurut metode Ellman. Hasil reaksi ini dapat diamati secara melalui pembentukan senyawa berwarna dan serapannya dapat diukur pada panjang gelombang visibel. Penentuan lokasi sampling pada penelitian didasarkan pada pertimbangan sebaran muatan polusi/diffuse pollution loads consideration. Ditetapkan enam lokasi pengambilan sampel air sungai yaitu GW-1, GW2, GW-3, GW-4, GW-5, dan GW-6 berturut-turut dari utara ke selatan. Dari keenam lokasi, GW-6 sebagai titik paling selatan dalam jalur pengambilan sampel menunjukkan penghambatan aktivitas AChE yang paling tinggi ditunjukkan dengan aktivitas AChE yang rendah.
\end{abstract}

Kata kunci: pencemaran air, kualitas air, asetilkolin esterase, Gajah Wong, metode Ellman, sungai.

\begin{abstract}
Gajah Wong River, one of the rivers in Yogyakarta city, was threatened by contamination of water pollutant due to the disposal waste of households, industrials, hospitals and hotels into its stream. The pollutions might cause the decreasing of water quality and raised the negative impact to living creatures that exploit it. River pollutions can be observed biochemically based on inhibition of acetylcholinesterase (AChE) enzyme activity by organophosphate and carbamate pesticide contamination. Biochemical assay in the analysis of water quality could be done according to the colorimetric of Ellman's method. The results of this reaction can be observed by measuring the formation of colored compounds at visible wavelengths. Determination of the sampling location in this research was performed based on diffuse pollution loads consideration. Six sampling sites was defined and named as GW-1, GW 2, GW 3, GW 4, GW-5, and $G W-6$, respectively in a row from north to south. As the results, water from GW-6 as the southernmost site in the sampling sites showed the highest inhibition of AChE activity.
\end{abstract}

Keywords: water pollution, water quality, acetylcholine esterase, Gajah Wong, Ellman's method, river.

\section{PENDAHULUAN}

Pencemaran air dapat didefinisikan sebagai penurunan karakteristik akibat adanya penambahan kontaminan antropogenik sehingga tidak memungkinkan bagi manusia untuk mengkonsumsinya serta tidak mendukung komunitas biotik seperti ikan dan makhluk lain yang tinggal pada lingkungan tersebut (Agrawal dkk., 2010). Saat ini, kontaminasi air oleh pestisida menjadi masalah ekologi sangat memprihatinkan karena kontaminasi pestisida tersebut dapat menyebabkan efek buruk pada kesehatan manusia dan hewan (Agarwal dkk., 2015). Pada negara tropis intensifikasi pertanian memicu peningkatan penggunaan pestisida yang dapat menimbulkan pencemaran lingkungan salah satunya pada sungai (Miranda dkk., 2008). 


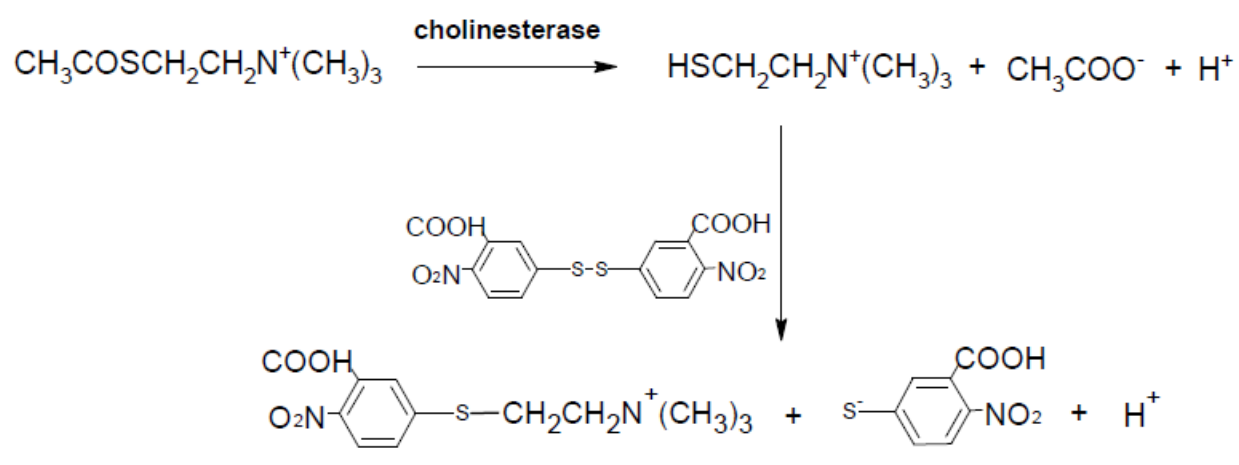

Gambar 1. Mekanisme reaksi yang terjadi pada metode Ellman (Pohanka dkk., 2008).

Pada daerah urban yang sedang berkembang, polusi air menjadi salah satu masalah potensial yang perlu diatasi, mengingat tingkat pencemaran air yang meningkat dari tahun ke tahun seiring dengan peningkatan populasi dan aktivitas masyarakat (Hendrawan dkk., 2013; Rakhi dkk., 2013). Sungai Gajah Wong merupakan salah satu sungai di Yogyakarta yang mengalami dampak pencemaran akibat semakin banyaknya bahan buangan dari limbah rumah tangga, industri, rumah sakit maupun hotel (Nuraini and Sunardi, 2010). Penggunaan air yang tidak memenuhi kriteria standar kualitas sesuai peruntukannya dapat menimbulkan gangguan terhadap kesehatan yang diakibatkan oleh keberadaan mikroorganisme patogen, zat kimia beracun dan zat radioaktif (Winata dan Hartantyo, 2013). Indikator pencemaran sungai tersebut dapat diamati secara fisik, kimiawi, mikrobiologis, radioaktivitas serta senyawa organik dan pestisida (Widiastuti dkk., 2015; PerGub DIY No. 20 tahun 2008).

Asetilkolinesterase (AChE) adalah enzim kunci sistem saraf yang berperan dalam pemutusan impuls saraf dengan mengkatalisis hidrolisis asetilkolin neurotransmiter (Colović dkk., 2013). Sebagai molekul target spesifik dari pestisida organofosfat dan karbamat, aktivitas dan penghambatan $\mathrm{AChE}$ telah diakui sebagai penanda awal keracunan pestisida pada sistem biologis (Lionetto dkk., 2013). Patogenesis penyakit Alzheimer sering dikaitkan dengan kekurangan neurotransmitter asetilkolin otak (Tabet, 2006). Kolinesterase otak ikan mas (Carassius auratus) mengalami penurunan setelah 96 jam terpapar azinfosmetil dan parathion secara in vivo (Ferrari dkk., 2004). Senyawa pestisida organofosfat dan karbamat dapat berikatan dengan sisi ester melalui fosforilasi maupun dekarbamilasi dan menginaktifkan enzim AChE (Lionetto dkk., 2013).

Uji biokimiawi untuk mengalisis kualitas air terhadap penghambatan $\mathrm{AChE}$ dapat dilakukan secara kolorimetrik sebagaimana dilakukan oleh Ellman dkk. (1961). Gambar 1 menunjukkan mekanisme reaksi di mana substrat asetiltiokolin dihidrolisis oleh AChE menjadi asam asetat dan tiokolin. Selanjutnya tiokolin bereaksi dengan asam 5,5'- ditiobis-(2-nitrobenzoat) (DTNB); dikenal sebagai reagen Ellman, membentuk asam 2-nitro-5tiobenzoat. Reaksi ini dapat diamati secara visibel dan serapannya dapat diukur pada $412 \mathrm{~nm}$ (Pohanka dkk., 2012). Pada penelitian ini dilaksanakan uji kualitas lingkungan Sungai Gajah Wong ditinjau dari penghambatan enzim asetilkolinesterase. Sampel air diambil pada enam titik sepanjang aliran Sungai Gajah Wong diikuti pengujian di laboratorium secara kolorimetrik menurut metode Ellman.

\section{METODE PENELITIAN}

\section{Bahan dan Alat}

Bahan yang digunakan dalam penelitian ini meliputi QuantiChrom ${ }^{\mathrm{TM}}$ Acetylcholinesterase Assay Kit DACE-100 (terdiri dari reagen, assay buffer dan kalibrator), sampel sampel air Sungai Gajah Wong yang diperoleh dari pengambilan pada beberapa titik berbeda, akuabidestilata, dan suatu merk obat serangga sebagai pembanding (kontrol positif). Alat yang digunakan meliputi seperangkat instrument Elisa Reader (DRG E-Liza Mat-3000), mikropipet Socorex, 96-well plate IWAKI, neraca analitik Scaltec SBC 22 (max 60/210 g, min 0,001 $\mathrm{g}, \mathrm{d}=0,01 / 0,1 \mathrm{mg}$ ), tabung sentrifugasi, dan seperangkat alat gelas.

\section{Lokasi dan Waktu Pengambilan Sampel}

Sampel air sungai Gajah Wong diambil dari enam titik sepanjang aliran sungai Gajah Wong (Tabel 1). Sampel ini diambil pada tanggal 22 Juli 2016 pada pukul 08.00 WIB. Pengambilan sampel disertai dengan dokumentasi foto serta pencatatan koordinat pada tiap lokasi tersebut. Sampel yang telah diambil tersebut disimpan dalam lemari pendingin pada suhu $4^{\circ} \mathrm{C}$ sebelum dilakukan pengukuran. 


\section{Metode Pengujian}

\section{Penyiapan blanko dan kalibrator}

Sejumlah $200 \mu \mathrm{L}$ assay buffer dan $200 \mu \mathrm{L}$ kalibrator masing-masing dimasukkan ke dalam lubang sumuran berbeda pada 96-well plate.

\section{Penyiapan reagen kerja}

Reagen kerja selalu dibuat baru dan digunakan dalam 30 menit. Tiap reaksi pada satu sumuran dibutuhkan $2 \mathrm{mg}$ reagen QuantiChrom ${ }^{\mathrm{TM}}$ Acetylcholinesterase Assay Kit DACE-100. Untuk mempersiapkan reagen kerja, dilakukan terlebih dahulu perhitungan jumlah reagen total yang dibutuhkan, ditimbang dan dimasukkan ke dalam tabung sentrifugasi. Untuk tiap $2 \mathrm{mg}$ reagen ditambahkan $200 \mu \mathrm{L}$ assay buffer, kemudian divorteks hingga larut.

\section{Penyiapan sampel}

Sampel air sungai dari enam lokasi, kontrol negatif berupa akuabidestilata, dan kontrol positif berupa suatu merk obat serangga, dipipet masingmasing $10 \mu \mathrm{L}$, dimasukkan ke dalam satu sumuran pada 96-well plate. Pada tiap sumuran ditambahkan masing-masing $190 \mu \mathrm{L}$ reagen kerja sehingga tiap sumuran berisi $200 \mu \mathrm{L}$ campuran sampel dan reagen kerja. Dilakukan masing-masing lima kali pengukuran.

\section{Pengukuran serapan dan uji aktivitas enzim AChE}

Sampel diinkubasi pada suhu kamar selama dua menit, waktu ini disebut initial time. Dilakukan pengukuran absorbansi menggunakan Elisa Reader (DRG E-Liza Mat-3000) dengan pengaturan filter pada 405 dan $450 \mathrm{~nm}$. Proses inkubasi dilanjutkan pada suhu kamar. Pengukuran absorbansi dilakukan dengan pengaturan yang sama setelah 10 menit, waktu ini disebut final time. Aktivitas enzim AChE (unit/L) ditetapkan dengan formula sebagai berikut: Aktivitas enzim $\mathrm{AChE}$ (unit/L) =

$$
\frac{A_{\text {final }}{ }^{-A_{\text {initial }}}}{A_{\text {kalibrator }}-A_{\text {blanko }}} \times n \times 200
$$

$200=$ tetapan aktivitas (unit/L) kalibrator saat pembacaan dilaksanakan pada menit ke-2 dan 10 $\mathrm{n}=$ faktor pengenceran
$\mathrm{A}_{\text {initial }}=$ serapan sampel pada pembacaan 2 menit $\mathrm{A}_{\text {final }}=$ serapan sampel pada pembacaan 10 menit $A_{\text {kalibrator }}=$ serapan kalibrator pada pembacaan 10 menit

$\mathrm{A}_{\text {blanko }}=$ serapan blanko pada pembacaan 10 menit.

Jika nilai aktivitas AChE tanpa pengenceran lebih besar dari 600 unit/L, maka sampel diencerkan kembali dengan assay buffer diikuti pengulangan uji. Perhitungan hasil dilakukan dengan mempertimbangkan faktor pengenceran. Satu unit AChE dinyatakan sebagai sejumlah enzim yang mengkatalisis pembentukan $1 \mu \mathrm{mol}$ tiokolin per menit pada suhu kamar dan kondisi pH 7,5. Rentang pengujian yang direkomendasikan berada pada kisaran 10-600 unit/L aktivitas AChE.

\section{HASIL DAN PEMBAHASAN}

\section{Penentuan Lokasi dan Pengambilan Sampel Air}

Lokasi pengambilan sampel ditentukan sepanjang Sungai Gajah Wong pada enam titik yang berpotensi terpapar cemaran. Pengambilan sampel dilakukan pada enam lokasi sebagaimana ditampilkan pada Tabel 1. Semakin besar dan luas sungai yang menjadi objek penelitian maka pertimbangan penentuan lokasinya semakin rumit. Penentuan lokasi sampling pada penelitian didasarkan pada pertimbangan sebaran muatan polusi/diffuse pollution loads consideration (Varekar dkk., 2015). Pertimbangan ini dinyatakan efektif diterapkan pada analisis kualitas lingkungan sungai yang besar dengan variasi tingkat pencemaran.

Berdasarkan diffuse pollution loads consideration telah ditentukan enam lokasi pengambilan sampel air dengan kode GW-1, GW2, GW-3, GW-4, GW-5, dan GW-6 berturut-turut dari utara ke selatan sepanjang sungai Gajah Wong (Gambar 2). GW-1 dan GW-2 merupakan aliran anak sungai Gajah Wong yang diduga menyumbangkan muatan cemaran, keduanya bertemu pada aliran utama sungai di daerah Nologaten. GW-3 merupakan lokasi aliran sungai

Tabel 1. Lokasi pengambilan sampel air sungai Gajah Wong.

\begin{tabular}{|c|c|c|}
\hline No & Kode & Lokasi dan koordinat \\
\hline 1 & GW-1 & $\begin{array}{l}\text { Jalan Asem Gede, Condong Catur, Depok, Sleman (utara RS JIH) } \\
\left(7^{\circ} 45^{\prime} 00.1^{\prime \prime S} 110^{\circ} 24^{\prime} 08.1^{\prime \prime E}\right)\end{array}$ \\
\hline 2 & GW-2 & $\begin{array}{l}\text { Jalan Pringgodani, Caturtunggal, Depok, Sleman (Jembatan Pringwulung- } \\
\text { Pringgodani) } \\
\left(7^{\circ} 46^{\prime} 19.6^{\prime \prime S} 110^{\circ} 23^{\prime} 40.4^{\prime \prime E}\right)\end{array}$ \\
\hline 3 & GW-3 & $\begin{array}{l}\text { Jalan Ori II, Papringan, Yogyakarta (utara Musem Affandi) } \\
\left(7^{\circ} 46^{\prime} 48.8^{\prime \prime S} 110^{\circ} 23^{\prime} 51.8^{\prime \prime E}\right)\end{array}$ \\
\hline 4 & GW-4 & $\begin{array}{l}\text { Jl. Laksda Adisucipto, Yogyakarta (kompleks kampus UIN Sunan Kalijaga) } \\
\left(7^{\circ} 47^{\prime} 10^{\prime \prime} \mathrm{S} 110^{\circ} 23^{\prime} 46^{\prime \prime E}\right)\end{array}$ \\
\hline 5 & GW-5 & $\begin{array}{l}\text { Jalan Balirejo, Muja Muju, Umbulharjo, Yogyakarta (Jembatan Balirejo) } \\
\left(7^{\circ} 47^{\prime} 42.8^{\prime \prime S} 110^{\circ} 23^{\prime} 47.1^{\prime \prime E}\right)\end{array}$ \\
\hline 6 & GW-6 & $\begin{array}{l}\text { Warungboto RT.30/RW.07, Yogyakarta (barat Gembira Loka) } \\
\left(7^{\circ} 48^{\prime} 35.2^{\prime \prime S} 110^{\circ} 23^{\prime} 39.2^{\prime \prime E}\right)\end{array}$ \\
\hline
\end{tabular}




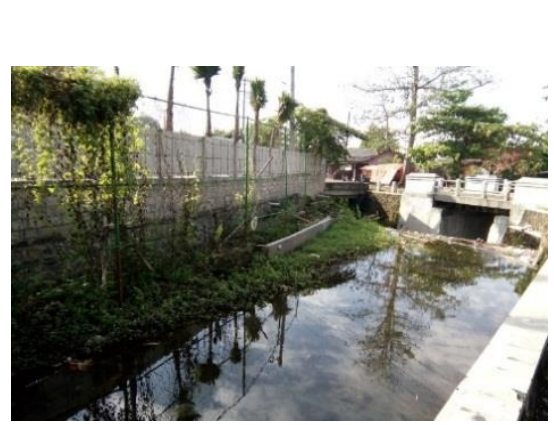

(a)

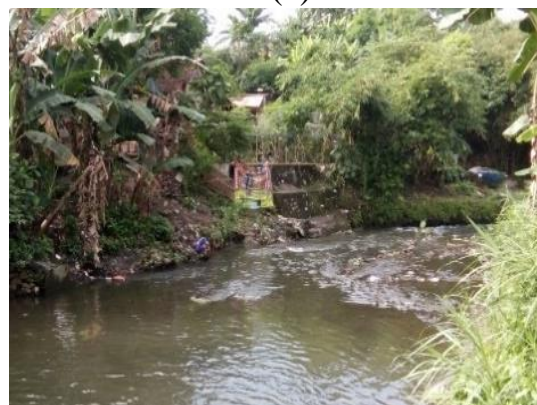

(d)

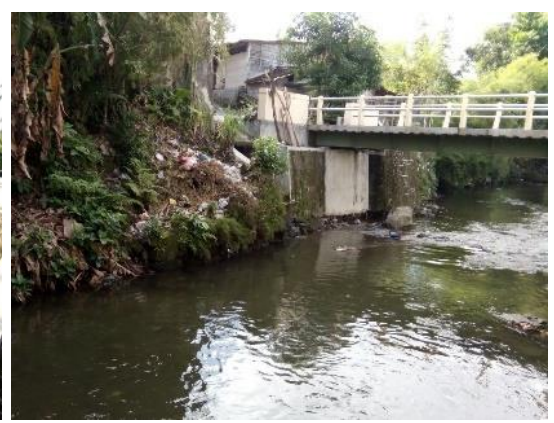

(b)

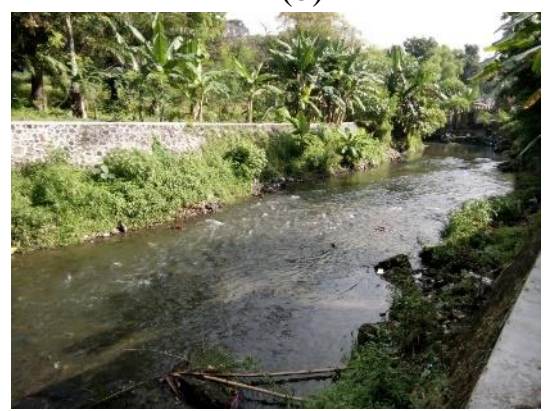

(e)

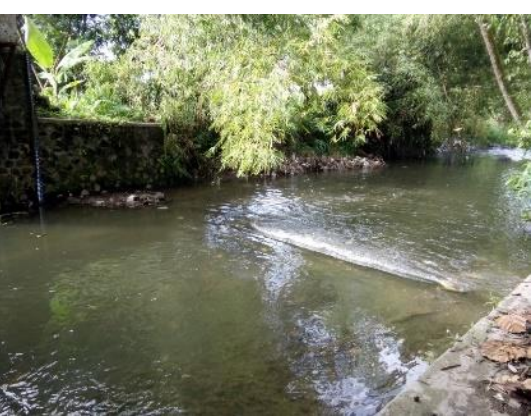

(c)

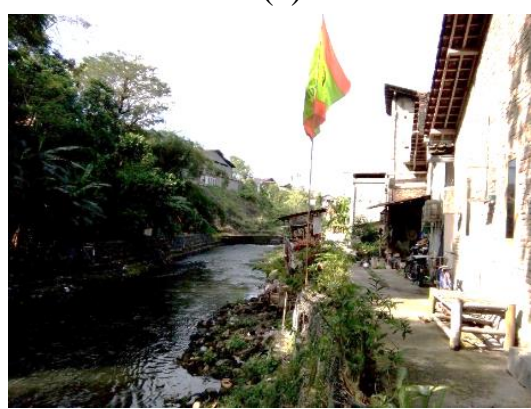

(f)

Gambar 2. Foto lokasi pengambilan sampel air. (a) GW-1; (b) GW-2; (c) GW-3; (d) GW-4; (e) GW-5; (f) GW-6.

setelah pertemuan aliran anak sungai GW-1 dan GW-2 sebelum memasuki area kota besar Yogyakarta. GW-4 merupakan aliran utama sungai Gajah Wong pada pusat kota Yogyakarta (Jl. Laksda Adisucipto) di mana terdapat berbagai aktivitas masyarakat. Selain pemukiman padat, area ini juga dipadati oleh pusat pertokoan, hotel, serta kampus perguruan tinggi. GW-5 merupakan aliran sungai di selatan kota yang berpotensi sebagai tempat terkumpulnya segala materi dan polusi yang dihasilkan oleh kota Yogyakarta. GW-6 sebagai titik akhir pengambilan sampel dipilih mengingat lokasinya yang terletak setelah area pabrik dan kebun binatang yang berpotensi terakumulasinya berbagai cemaran yang berbahaya bagi lingkungan.

\section{Pengukuran Serapan dan Uji Aktivitas Enzim AChE}

Perhitungan aktivitas enzim AChE dapat dilakukan secara kolorimetrik (Ellman dkk., 1961). Substrat asetiltiokolin dihidrolisis oleh AChE menjadi asam asetat dan tiokolin. Reagen-kit yang mengandung DTNB dapat bereaksi dengan tiokolin sehingga menghasilkan senyawa 2-nitrobenzoat-5merkaptotiokolin dan 2-nitro-5-tiobenzoat berwarna kuning. Pengukuran aktivitas enzim AChE ini dilakukan menggunakan Elisa Reader dengan pengaturan filter pada 405 dan $450 \mathrm{~nm}$. Sebelum uji dilakukan sampel air disimpan dalam lemari pendingin pada suhu $4{ }^{\circ} \mathrm{C}$ untuk menjaga stabilitas sampel sehingga tidak kehilangan aktivitasnya terhadap enzim AChE (Gupta dkk., 2016). Aktivitas enzim AChE diukur pada suhu kamar dan

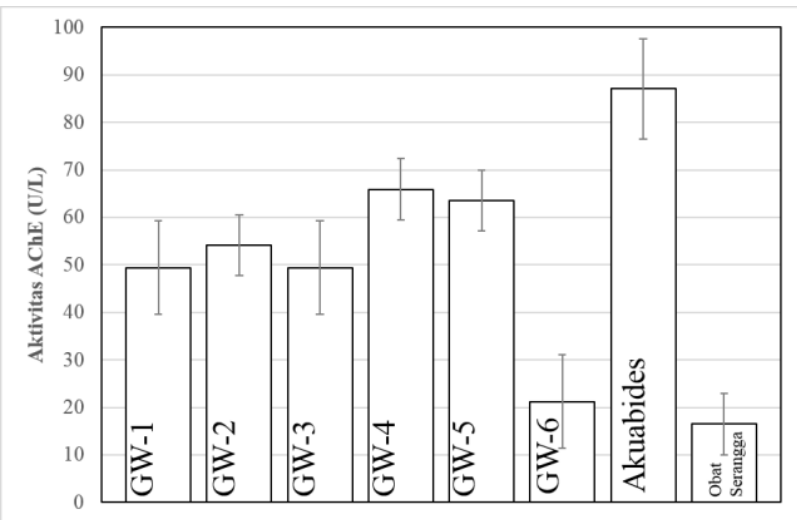

Gambar 3. Aktivitas enzim AChE sebagai pengaruh air sungai Gajah Wong pada setiap lokasi sampling $(\mathrm{n}=5)$.

kondisi $\mathrm{pH}$ dalam rentang 6,8-7,5. Hal ini dilakukan dengan tujuan meminimalkan variasi aktivitas karena faktor lain seperti pengaruh temperatur dan keasaman air (Worek dkk., 2012; Rebechi-Baggio dkk., 2016). Hasil pengukuran aktivitas enzim AChE akibat pengaruh kontrol positif, kontrol negatif, dan air sungai Gajah Wong pada enam lokasi berbeda ditampilkan pada Gambar 3.

Berdasarkan Gambar 3 dapat diamati bahwa aktivitas enzim AChE yang dipengaruhi oleh air sungai Gajah Wong dari keenam lokasi pengambilan sampel. Dilakukan pengukuran aktivitas AChE akibat pengaruh akuabidestilata sebagai kontrol negatif dan suatu produk obat serangga sebagai kontrol positif. Nilai aktivitas AChE akibat pengaruh sampel GW-1 diperoleh 
sebesar 49,412 $\pm 9,84$ unit/L; GW-2 sebesar $54,118 \pm 6,44$ unit/L; GW-3 sebesar 49,412 $\pm 9,84$ unit/L; GW-4 sebesar 65,882 $\pm 6,44$ unit/L; GW-5 sebesar 63,529 $\pm 6,44$ unit/L; GW-6 sebesar $21,176 \pm 9,84$ unit/L; akuabidestilata sebesar $87,059 \pm 10,52$ unit/L; dan obat serangga sebesar $16,471 \pm 6,44$ unit/L. Dari keenam lokasi pengambilan, GW-6 menunjukkan pengaruh penghambatan AChE yang tinggi dibuktikan nilai aktivitas AChE yang rendah dan hampir mendekati penghambatan obat serangga sebagai kontrol positif. Hal ini diduga diakibatkan akumulasi cemaran sepanjang aliran sungai yang membelah kota Yogyakarta dan mengalir dari utara ke selatan.

\section{KESIMPULAN}

Kualitas lingkungan Sungai Gajah Wong dapat diuji potensinya terhadap penghambatan aktivitas enzim AChE sebagai akibat kemungkinan cemaran pestisida. Dari keenam lokasi, GW-6 sebagai titik paling selatan dalam jalur pengambilan sampel menunjukkan penghambatan aktivitas AChE yang paling tinggi ditunjukkan dengan aktivitas AChE yang rendah.

\section{UCAPAN TERIMAKASIH}

Peneliti mengucapkan terima kasih kepada Lembaga Penelitian dan Pengabdian Masyarakat, Universitas Sanata Dharma yang telah membiayai penelitian ini melalui Hibah Penelitian Internal tahun anggaran 2016. Peneliti juga mengucapkan terima kasih atas dukungan teknis yang diberikan oleh Pusat Studi Lingkungan Universitas Sanata Dharma hingga penelitian ini dapat berjalan.

\section{DAFTAR PUSTAKA}

Agarwal, A., Prajapati, R., Singh, O.P., Raza, S.K., dan Thakur, L.K., 2015. Pesticide Residue in Water-A Challenging Task in India. Env. Monit Assess 187, 4287.

Agrawal, A., Pandey, R.S., dan Sharma, B., 2010. Water Pollution with Special Reference to Pesticide Contamination in India. J. Water Resour. Prot. 02, 432-448.

Colović, M.B., Krstić, D.Z., Lazarević-Pašti, T.D., Bondžić, A.M., dan Vasić, V.M., 2013. Acetylcholinesterase Inhibitors: Pharmacology and Toxicology. Curr. Neuropharmacol. 11, 315-35.

Ellman, G.L., Courtney, K.D., Andres, V., dan Featherstone, R.M., 1961. A New and Rapid Colorimetric Determination of Acetylcholinesterase Activity. Biochem. Pharmacol. 7, 88-95.
Ferrari, A., Venturino, A., dan Pechen De D'Angelo, A.M., 2004. Time Course of Brain Cholinesterase Inhibition and Recovery Following Acute and Subacute Azinphosmethyl, Parathion and Carbaryl Exposure in The Goldfish (Carassius auratus). Ecotoxicol. Environ. Saf. 57, 420-425.

Gupta, V.K., Pathak, A., Siddiqi, N.J., dan Sharma, B., 2016. Carbofuran Modulating Functions of Acetylcholinesterase from Rat Brain In Vitro. Adv. Biol. 2016, 1-6.

Hendrawan, D., Widarnako, S., Moersidik, S.S., dan Triweko, R.W., 2013. Evaluation of Centralized WWTP and The Need of Communal WWTP in Supporting Community-Based Sanitation in Indonesia. Eur. Sci. J. 9, 229-239.

Lionetto, M.G., Caricato, R., Calisi, A., Giordano, M.E., dan Schettino, T., 2013. Acetylcholinesterase as A Biomarker in Environmental and occupational Medicine: New Insights and Future Perspectives. Biomed Res. Int. 2013, 1-8.

Miranda, K., Cunha, M.L.F., Dores, E.F.G.C., dan Calheiros, D.F., 2008. Pesticide Residues in River Sediments from the Pantanal Wetland, Brazil. J. Environ. Sci. Health. B. 43, 717722.

Nuraini, E., dan Sunardi, 2010. Kualitas Lingkungan Sungai Code dan Gajahwong Ditinjau dari Kadar $\mathrm{Cu}$ dan $\mathrm{Cr}$ Dalam Cuplikan Sedimen. Pros. Pertem. Ilm. XXIV HFI Jateng dan DIY 328-338.

PerGub DIY No. 20, 2008, Peraturan Gubernur tentang Baku Mutu Air di Provinsi Daerah Istimewa Yogyakarta.

Pohanka, M., Vlček, V., Žd’árová-Karasová, J., Kuča, K., Cabal, J., A., dan Fusek, J., 2012. Acetylcholinesterase Based Colorimetric Dipsticks for Military Performance: Principles and Construction. Adv. Mil. Technol. 7, 8391.

Pohanka, M., Hrabinova, M., dan Kuca, K., 2008. Diagnosis of Intoxication by The Organophosphate VX: Comparison Between An Electrochemical Sensor and Ellman's Photometric Method. Sensors 8, 5229-5237.

Rakhi, S., Reza, A.H.M., Hossen, M., dan Hossain, Z., 2013. Alterations in Histopathological Features and Brain Acetylcholinesterase Activity in Stinging Catfish Heteropneustes fossilis Exposed to Polluted River Water. Int. Aquat. Res. 5, 1-18.

Rebechi-Baggio, D., Richardi, V.S., Vicentini, M., Guiloski, I.C., Assis, H.C.S. de, dan NavarroSilva, M.A., 2016. Factors that Alter The 
Biochemical Biomarkers of Environmental Contamination in Chironomus sancticaroli (Diptera, Chironomidae). Rev. Bras. Entomol. 60, 341-346.

Tabet, N., 2006. Acetylcholinesterase Inhibitors for Alzheimer's Disease: Anti-Inflammatories in Acetylcholine Clothing. Age Ageing 35, 336338.

Varekar, V., Karmakar, S., Jha, R., dan Ghosh, N.C., 2015. Design of Sampling Locations for River Water Quality Monitoring Considering Seasonal Variation of Point and Diffuse Pollution Loads. Env. Monit Assess 187, 1-26.

Widiastuti, E., Kustono, Adiarto, dan Nurliyani, 2015. The Impact of The Local Dairy Cattle
Farm Toward The River Water Quality in Gunungpati Subdistrict Central Java. Int. J. Sci. Eng. 8, 15-21.

Winata, E., dan Hartantyo, E., 2013. Kualitas Air Tanah di Sepanjang Kali Gajah Wong Ditinjau dari Pola Sebaran Escherichia coli (Studi Kasus Kecamatan Umbulharjo). J. Fis. Indones. XVII, 8-11.

Worek, F., Eyer, P., dan Thiermann, H., 2012. Determination of Acetylcholinesterase Activity by the Ellman Assay: A Versatile Tool for In Vitro Research on medical Countermeasures Against Organophosphate Poisoning. Drug Test. Anal. 4, 282-291. 